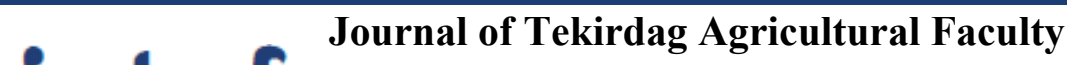

\section{Comparative Investment Analysis of Agricultural Irrigation Systems}

\author{
Tarımsal Sulama Sistemlerinin Karşılaştırmalı Yatırım Analizi
}

Süheyla AĞIZAN ${ }^{*}$, Zeki BAYRAMOĞLU ${ }^{2}$

\begin{abstract}
The return of socio-economic prosperity in the population and developed countries in the world has increased the demand for agricultural products. It increases the need for agricultural water in production and production conditions to meet the increasing demand. Irrigation methods and irrigation systems are needed to meet irrigation water. As a matter of fact, which method or system is chosen for study researches and cost calculations. In this study, comparative economic analysis is aimed for irrigation. For this purpose, plant costs and operating costs of irrigation systems are determined, and investment costs are calculated. In addition, a cost-benefit analysis is performed for irrigation systems and the net present value and internal rate of return are calculated. As a result of the calculation; 1.02 in sprinkler irrigation systems, 1.13 in drip irrigation systems, 1.54 in center-pivot irrigation systems and 1.57 in linear move irrigation systems. According to these values, the cost ratio of linear move irrigation system is higher than other systems. The fact that the cost-benefit ratio is greater than 1 indicates that the investments are profitable. The net present values of irrigation systems are determined as $\$ 25.90$ in sprinkler irrigation, \$ 179.56 in drip irrigation, \$ 833.00 in center-pivot irrigation and \$ 844.46 in linear move irrigation and in terms of net present value, linear move irrigation systems come to the fore. In addition, the internal profitability rates of irrigation systems are calculated, and the rate of sprinkler irrigation was found to be $20.42 \%$, in drip irrigation $29.09 \%$, in center-pivot irrigation $76.16 \%$ and in linear move irrigation $76.41 \%$. According to internal profitability rates, the most profitable system is linear move irrigation system. As a result, linear move irrigation systems are more profitable than other systems.
\end{abstract}

Keywords: Benefit-Cost Ratio, İnternal Rate of Return, Net Present Value, Irrigation Systems, Investment Analysis.

\footnotetext{
1*Sorumlu Yazar/Corresponding Author: Süheyla AĞIZAN, Selcuk University, Agricultural Faculty, Department of Agricultural Economics, Konya/Turkey, E-mail: agizansuheyla@gmail.com (D) OrcID: 0000-0002-9210-1671

${ }^{2}$ Zeki BAYRAMOĞLU, University, Agricultural Faculty, Department of Agricultural Economics, Konya/Turkey. E-mail: zbayramoglu@selcuk.edu.tr 10 OrcID: 0000-0003-3258-3848

Atıf/Citation: Ağızan S., Bayramoğlu Z,. Comparatıve Investment Analysıs of Agrıcultural Irrıgatın Systems. Tekirdağ Ziraat Fakültesi Dergisi, 18 (2), $222-233$.
} 


\section{Özet}

Dünya'da nüfus artışı ve gelişmiş ülkelerde sosyo ekonomik refahın getirisi tüketim çeşitliliği tarım ürünlerine olan talebi artırmıştır. Artan talebin karşılanması için üretim artışı ve üretim artışı da tarımsal su ihtiyacını arttırmaktadır. Sulama suyunun karşılanmasında ise sulama yöntemlerine ve sulama sistemlerine ihtiyaç duyulmaktadır. Nitekim hangi yöntemin veya sistemin seçilmesi, yapılacak etüt araştırmaları ve maliyet hesaplamaları sonucunda işletmeye uygun olanın karar verilmesi verimlilik açısından önemlidir. Bu çalışmada kapsamında da sulama sistemlerinin karşılaştırmalı ekonomik analizi amaçlanmıştır. Bu amaca yönelik olarak sulama sistemlerinin tesis masrafları ve işletmecilik masrafları tespit edilerek yatırım masrafları hesaplanmışır. Ayrıca sulama sistemlerine göre fayda masraf analizi yapılmış ve net bugünkü değer ile iç karlılık oranları hesaplanmıştır. Hesaplama sonucunda sulama sistemlerinin fayda masraf oranları; yağmurlama sulama sistemlerinde 1.02, damla sulama sistemlerinde 1.13, dairesel hareketli sulama sistemlerinde 1.54 ve doğrusal hareketli sulama sistemlerinde 1.57 olarak belirlenmiştir. Bu değerlere göre doğrusal hareketli sulama sisteminin fayda masraf oranı diğer sistemlere göre daha yüksek tespit edilmiştir. Fayda masraf oranının 1'den büyük olması yatırımların kârlı olduğunu göstermektedir. Sulama sistemlerinin net bugünkü değerleri yağmurlama sulamada 25.90 \$, damla sulamada 179.56 \$, dairesel hareketli sulamada 833.00 \$ ve doğrusal hareketli sulamada 844.46 \$ olarak belirlenmiş olup net bugünkü değer bakımından da doğrusal hareketli sulama sistemleri ön plana çıkmaktadır. Ayrıca sulama sistemlerinin iç kârlılık oranları hesaplanmış ve yağmurlama sulamada \%20.42, damla sulamada $\% 29.09$, dairesel hareketli sulamada $\% 76.16$, doğrusal hareketli sulamada $\% 76.41$ olarak belirlenmiştir. İç kârlılık oranlarına göre en kârlı sistem doğrusal hareketli sulama sistemidir. Sonuç olarak doğrusal hareketli sulama sistemleri diğer sistemlere göre daha kârlı yatırımlardır.

Anahtar Kelimeler: Fayda Masraf Oranı, İç Karlılık Oranı, Net Bugünkü Değer, Sulama Sistemleri, Yatırım Analizi. 


\section{Introduction}

Water is an indispensable natural resource for living things. The use of water for various purposes (irrigation, transportation, industry, drinking, fishing, etc.) has increased its importance every day. $71 \%$ of the water availability in the world is used in agricultural sector, $18 \%$ in industrial sector and $11 \%$ for domestic purposes. The freshwater consumption in Turkey, in the agricultural sector, $73 \%$, in industry $\% 11$, and $\% 16$ for domestic purposes (Sutema, 2017). Agriculture is the most important water user in Turkey and in the World (Çakmak et al. 2014).

Since the world population increases day by day, the demand for agricultural products is increasing. Therefore, the amount of production obtained from the unit area should be increased to meet the increasing need. Increase in agricultural production can be provided with applications such as land consolidation, agricultural struggle, land reclamation, quality seed, fertilization, irrigation and so on. Irrigation is much more important in countries which is in arid and semi-arid climates such as Turkey.

Irrigation; In the growing and flowering periods of plants, cultivated plants, which cannot be met with natural precipitation, are defined as a versatile application that increases the effectiveness of other agricultural inputs by giving the water needs of the plants to the plant root area with different irrigation methods. According to this definition, while irrigation method is brought to the field with the help of transmission and distribution elements of irrigation water, it is expressed as the way water is given to the plant root area, while irrigation methods is brought to the field with the help of transmission and distribution elements of irrigation water is the way the water is given to the plant root area. The irrigation system covers all of the necessary means to bring the area to be irrigated from the water source and distribute it in the land (Ağızan, 2018).

While the irrigation method is selected first some factors considered such as existing water source, soil, plants, climate, economic, social, and cultural situation etc. The irrigation system of the selected irrigation method is planned, and the planned irrigation system is being projected, installed, and operated. It is not enough that the irrigation systems are only technically suitable. They should also be appropriate and effective with their economic aspects. The systems should be compared in terms of technical and economic aspects and the irrigation system with the lowest investment cost and high product efficiency should be preferred (Erdem, 2018).

Many studies have so far been conducted on the comparison of irrigation systems. Demir et al. (1995) compared the drip irrigation system and the furrow irrigation system in their studies on strawberry yield under Bursa conditions, and it was determined that more efficiency was achieved with the drip irrigation system and $18.5 \%$ more savings. Soydam and Cakmak (2006) compared the collective pressure irrigation systems economically and as a result, it was determined that drip irrigation systems provided more benefits than sprinkling. In studies carried out to date, economical comparisons of furrow, sprinkler and drip irrigation systems were generally made. However, in recent years, the application of new technologies in agriculture is known to increase efficiency and efficiency, as well as to save energy use, decrease in production costs and save labor, and to determine the benefits that modern irrigation techniques (circular motion and linear motion) provide to producers in this field.

The aim of this study is to determine the irrigation systems applied in agricultural production enterprises and to compare the comparative investment costs of irrigation systems with net present value, internal profitability ratio and benefit expense ratio methods.

\section{Materials and Methods}

The data used in the study were compiled from primary and secondary data sources. Primary data belong to the production period of 2017 and was obtained by conducting a survey with agricultural enterprises located in Çumra district of Konya. The primary data were surveyed with 115 manufacturers determined by stratified random sampling method. Secondary data were obtained from the reports and statistics of various agricultural institutions.

Costs in irrigation systems consist of two parts as investment and management costs. While calculating these expenses, 2017 dollar rate was taken into consideration. Calculations were made by determining one dollar of that year as 3.79 Turkish Lira (Anonim, 2017). In the investment expenses, purchase prices are obtained in accordance with the declarations of the manufacturers, and unexpected expenses are considered as $10 \%$ of the purchase prices 
and added to the purchase price. In the general expenses calculation, $10 \%$ of the total purchase price and unexpected expenses were taken (Talmaç, 2006).

Changing costs, which are included in the operating costs, have been considered the changing costs of the relevant production activities. While depreciation costs are taken $10 \%$ of the related irrigation systems, $16 \%$ of the purchase prices of the related irrigation systems are taken as interest costs. When calculating permanent labor costs and maintenance-repair costs, the statements of operators are considered.

Net present value; is the difference between the sum of the present value of the money inflows that will be provided over the economic life of the investment over a predetermined discount rate and the sum of the present value of the money outflows required by the investment over this specific discount rate (Akgüç 1994).

$$
N P V=\sum_{t=m+1}^{t=n} \frac{G_{t}}{(1+i)^{t}}+\frac{H_{t}}{(1+i)^{t}}-\sum_{t=0}^{m} \frac{I_{t}}{(1+i)^{t}}
$$

NPV: Net present value

Gt: Project's revenue in " $t$ " year.

It: Investment amount of the project in year $\mathrm{t}$

$\mathrm{m}$ : Completion time of the project

$\mathrm{n}$ : The utilization life of the project

i: Reduction Ratio

Ht: Scrap value at the end of the project's utilization life (Albayrak, 2009).

The calculation result can be positive, negative and zero. NPV $>0$ indicates that the project will be profitable, $\mathrm{NPV}<0$ indicates that the Project will lose and if NPV $=0$ indicates that the break-even point of the project (Eq.1). The internal rate of return is the discount rate that equates the present value of the cash inflows to the present value of the cash outflows (Senkondo et al., 2004). In this analysis method, the expected profitability rate of investment varies according to project risk, investor expectation and various parameters. The minimum value of the profitability ratio expected from the investment is considered as the capital cost. As a result of the comparison, it is decided to accept or reject the project. For a project to be accepted, LFPR must be greater than the minimum reduction rate accepted by the investor. If the calculated LFPR is lower than the expected profitability of the investment, the project is rejected in a choice between alternative projects, the project with the highest rate is given priority. Internal profitability ratio is smaller than the discount rate which makes NPL positive, and it is smaller than the negative rate (ip $<$ ir $<$ in) (Kavak, 2012).

$$
I P R=\sum_{t=m+1}^{m+n} \frac{N N G_{t}}{(1+i)^{t}}=\sum_{t=0}^{m} \frac{I_{t}}{\left(1+i_{r}\right)^{t}}
$$

The formula defines the IPR as internal profitability ratio, defines the NNGt as the value of investment amounts in the year $t$, defines the " $n$ " the economic life of the facility, defines the " $m$ " the construction time of the project and defines the "ir" the internal rate of return (Eq.2). The benefit / cost ratio is the ratio of the present value of the benefits (cash inflows) that a project will provide during its economic and the expenditures made to the investment (cash outputs) to the sum of the present values (Albayrak 2009).

$$
\frac{B}{C}=\frac{\left(\sum_{t=m+1}^{t=n} \frac{G_{t}}{(1+i)^{t}}+\frac{H}{(1+i)^{t}}\right)}{\sum_{t=0}^{t=m} \frac{I_{t}}{(1+i)^{t}}}
$$

The formula defines "B/C" as benefit/cost ratio, defines "Gt" as benefits of the project in t year (cash inputs), defines " $\mathrm{H}$ " as scrap value of the project, defines "It" as the cost of the project in $\mathrm{t}$ year (cash outflows) defines " $m$ " completion time of the project, defines " $n$ " as economic life of the project, and defines " $\mathrm{i}$ " as reduction ratio (Eq.3).

The calculation result can be equal to 1 , smaller than 1 and bigger than 1 . If $B / C$ ratio $=1$ it means that the project at break-even point and as a result the income of the project is equal to the investment of the project If $\mathrm{F} / \mathrm{M}$ $<1$ it means that the income of the Project below the cost of the project, so it is not acceptable because the project will be lost. If $\mathrm{F} / \mathrm{M}>1$ it means that the income of the project is more than the investment of the project. And as a result, project will be accepted. In addition, if the $\mathrm{B} / \mathrm{C}$ ratio is bigger than 1 , profitability increases with $\mathrm{B} / \mathrm{C}$ ratio 


\section{Results and Discussion}

The production costs of agricultural products and the investment costs of the irrigation systems differ in terms of products. In this study, the production patterns and the irrigation systems used in the agricultural enterprises are examined. It has been determined that wheat, barley, sugar beet, grain maize, silage maize, sunflower, alfalfa, vetch and carrot are produced in the research area. Average land width per plant is determined as 218.87 decares, $25.48 \%$ wheat, $21.93 \%$ sugar beet, $16.11 \%$ barley and $13.21 \%$ grain maize are grown. In Irrigation systems, sprinkler, drip, circular moving, and linear moving irrigation systems have been used. Average instrument machinery capital per operation is calculated at $\$ 83,118.85$. This value is formed by $23.99 \%$ are sprinkler irrigation systems, $9.29 \%$ are drip irrigation systems, $2.02 \%$ are linear moving irrigation systems and $1.73 \%$ are circular moving irrigation systems. The capital ratio of the total irrigation systems is determined as $37.03 \%$. Linear and circular moving irrigation systems are just preferred by enterprises with more than 200 decares of land width. The reason is that mobile irrigation systems increase the investment cost in small lands and topographical conditions prevent the use of these systems. In the study, it is determined which irrigation systems are preferred and the investment analysis of the irrigation systems used over the average land (da) widths of the products. The purchase price is considered in accordance with the manufacturers' declarations.

The wheat production area in the examined enterprises is $6.414 \mathrm{da}$ and $83.6 \%$ is irrigated by sprinkler irrigation system and $16.4 \%$ by drip irrigation system. The barley production area is 4.054 da. The preferred irrigation systems for barley production are like wheat. $88.0 \%$ of the barley production areas are irrigated by sprinkler and $12.0 \%$ by drip irrigation systems. The drip irrigation system is generally preferred in the crops which are sowed in order Recently because of irrigation costs increased, productivity increased by using drip irrigation and agricultural supports given by the state as a result irrigation system can be used in wheat and barley production. As a result of the research sugar beet production area is found $5520 \mathrm{da} .73 .0 \%$ of this area is irrigated with sprinkler, $15.0 \%$ drip, $7.0 \%$ circular moving and 5.0\% linear moving irrigation systems (Table 1).

Table 1. Distribution of Product Groups and Irrigation Systems in Investigated Enterprises (da and \%)

\begin{tabular}{|c|c|c|c|c|c|c|c|c|c|c|c|}
\hline & & Wheat & Barley & $\begin{array}{c}\text { Sugar } \\
\text { beet }\end{array}$ & $\begin{array}{l}\text { Grain } \\
\text { Maize }\end{array}$ & $\begin{array}{l}\text { Silage } \\
\text { Maize }\end{array}$ & Sunflower & Clover & Vetch & Carrot & Total \\
\hline \multirow{3}{*}{$\begin{array}{l}\text { Sprinkler } \\
\text { İrrigation }\end{array}$} & da & 5.365 & 3.569 & 4.03 & 1.995 & 1.073 & 1.156 & 1.263 & 489 & 360 & \multirow[b]{2}{*}{19.300} \\
\hline & $(\%)^{1}$ & 83,6 & 88 & 73 & 60 & 65 & 85,8 & 91,5 & 80 & 81,8 & \\
\hline & $(\%)^{2}$ & 27.8 & 18.49 & 20.88 & 10.34 & 5.56 & 5.99 & 6.54 & 2.53 & 1.87 & 100 \\
\hline \multirow{3}{*}{$\begin{array}{l}\text { Drip } \\
\text { İrrigation }\end{array}$} & da & 1.049 & 485 & 828 & 499 & 297 & 192 & 118 & 122 & 80 & \multirow{2}{*}{3.670} \\
\hline & $(\%)^{1}$ & 16.4 & 12 & 15 & 15 & 18 & 14.2 & 8.5 & 20 & 18.2 & \\
\hline & $(\%)^{2}$ & 28.58 & 13.22 & 22.56 & 13.6 & 8.09 & 5.23 & 3.22 & 3.32 & 2.18 & 100 \\
\hline Circular & da & & & 386 & 332 & 115 & & & & & \multirow{2}{*}{833} \\
\hline Moving & $(\%)^{1}$ & & & 7 & 10 & 7 & & & & & \\
\hline İrrigation & $(\%)^{2}$ & & & 46.34 & 39.86 & 13.81 & & & & & 100 \\
\hline Linear & da & & & 276 & 499 & 167 & & & & & \multirow{2}{*}{942} \\
\hline Moving & $(\%)^{1}$ & & & 5 & 15 & 10.1 & & & & & \\
\hline İrrigation & $(\%)^{2}$ & & & 29.3 & 52.97 & 17.73 & & & & & 100 \\
\hline Total & da & 6.414 & 4.054 & 5.52 & 3.325 & 1.652 & 1.348 & 1.381 & 611 & 440 & \\
\hline
\end{tabular}

$(\%)^{1}=$ Distribution of Irrigation Systems Used in Product Groups Grown in Examined Enterprises

$(\%)^{2}=$ Distribution of Products in the System Groups Used by the Examined Businesses

Table 1 shows the total amount of cultivated land according to the irrigation systems and the shares of the products within these land quantities. According to the table, the total of the land width of the sprinkler irrigation system was 19.300 da. The irrigated area which used sprinkler irrigation system $27.80 \%$ of wheat, $20.88 \%$ of sugar beet and $18.49 \%$ of barley is grown. The amount of irrigated land with drip irrigation system is $3.670,28.58 \%$ of wheat, $22.56 \%$ sugar beet, $13.60 \%$ grain maize and $13.22 \%$ barley.

It is determined that 9 types of crops were irrigated with sprinkler and drip irrigation systems, but only sugar beet, grain and silage maize plants are irrigated with circular and linear moving irrigation systems. While the highest share in the circular moving irrigation system is sugar beet (46.34\%), it has grain maize $(52.97 \%)$ in the linear moving irrigation system. In this study, investment costs, management costs, management expenses, management expenses incurred current day and total costs are calculated according to systems and the costs of investment and management of irrigation systems of agricultural holdings are given in Table 2. 
According to the table, the total investment cost per enterprise is calculated as $\$ 54,885.63$ in the sprinkler system, $\$ 25,530.76$ in the drip irrigation system, $\$ 21,129.23$ in the circular moving irrigation system and $\$ 20,197.19$ in the linear moving irrigation system. The total investment expenditure in decare is $\$ 247.41$ in sprinkler irrigation system, \$ 278.26 in drip irrigation system, \$ 228.29 in circular moving irrigation system and $\$ 235.85$ in linear moving irrigation system. Total operating costs per enterprise are calculated as $\$ 42,408.48$ in sprinkler irrigation system, $\$ 17,760.70$ in drip irrigation system, $\$ 19,713.73$ in circular moving irrigation system and $\$ 17,098.65$ in linear moving irrigation system. Field calculations, maintenance, harvests, and items related to production inputs were taken into consideration while calculating the variable costs included in the management costs.

Table 2. Investment and Management Costs of Irrigation Systems (\$)

\begin{tabular}{|c|c|c|c|c|c|c|c|c|c|}
\hline \multirow{3}{*}{\multicolumn{2}{|c|}{ Cost Elements }} & \multicolumn{8}{|c|}{ Irrigation Systems } \\
\hline & & \multicolumn{2}{|c|}{$\begin{array}{c}\text { Sprinkler Irrigation } \\
\text { System }\end{array}$} & \multicolumn{2}{|c|}{$\begin{array}{l}\text { Drip Irrigation } \\
\text { System }\end{array}$} & \multicolumn{2}{|c|}{$\begin{array}{l}\text { Circular Moving } \\
\text { Irrigation System }\end{array}$} & \multicolumn{2}{|c|}{$\begin{array}{l}\text { Linear Moving } \\
\text { Irrigation System }\end{array}$} \\
\hline & & $\begin{array}{c}\text { Per } \\
\text { enterprise }\end{array}$ & $\begin{array}{c}\text { Per } \\
\text { Decares }\end{array}$ & $\begin{array}{c}\text { Per } \\
\text { enterprise }\end{array}$ & $\begin{array}{c}\text { Per } \\
\text { Decares }\end{array}$ & $\begin{array}{c}\text { Per } \\
\text { enterprise }\end{array}$ & $\begin{array}{c}\text { Per } \\
\text { Decares }\end{array}$ & $\begin{array}{c}\text { Per } \\
\text { enterprise }\end{array}$ & $\begin{array}{c}\text { Per } \\
\text { Decares }\end{array}$ \\
\hline \multirow{4}{*}{$\begin{array}{l}\text { Investment } \\
\text { Costs }\end{array}$} & Purchase Price & $47,726.64$ & 215.14 & $22,200.66$ & 241.97 & $18,373.24$ & 198.51 & $17,562.78$ & 205.08 \\
\hline & Unexpected Expenses & $4,772.66$ & 21.51 & $2,220.07$ & 24.20 & $1,837.32$ & 19.85 & $1,756.28$ & 20.51 \\
\hline & General Expenses & $2,386.33$ & 10.76 & $1,110.03$ & 12.10 & 918.66 & 9.93 & 878.14 & 10.26 \\
\hline & $\begin{array}{l}\text { Total Investment } \\
\text { Expense }\end{array}$ & $54,885.63$ & 247.41 & $25,530.76$ & 278.26 & $21,129.23$ & 228.29 & $20,197.19$ & 235.85 \\
\hline \multirow{6}{*}{$\begin{array}{l}\text { Management } \\
\text { Costs }\end{array}$} & Variable Costs & $28,180.66$ & 127.03 & $11,395.36$ & 124.20 & $14,590.92$ & 157.64 & $12,224.58$ & 142.75 \\
\hline & Depreciation Expense & $4,772.66$ & 21.51 & $2,220.07$ & 24.20 & $1,837.32$ & 19.85 & $1,756.28$ & 20.51 \\
\hline & $\begin{array}{l}\text { Irrigation İnterest } \\
\text { Expense }\end{array}$ & $7,636.26$ & 34.42 & $3,552.11$ & 38.72 & $2,939.72$ & 31.76 & $2,810.04$ & 32.81 \\
\hline & Permanent Labor Cost & 767.00 & 3.46 & 84.19 & 0.92 & 26.61 & 0.29 & 30.69 & 0.36 \\
\hline & $\begin{array}{l}\text { Maintenance and } \\
\text { Repair Cost }\end{array}$ & $1,051.89$ & 4.74 & 508.98 & 5.55 & 319.16 & 3.45 & 277.05 & 3.23 \\
\hline & Total Costs & $42,408.48$ & 191.17 & $17,760.70$ & 193.58 & $19,713.73$ & 212.99 & $17,098.65$ & 199.67 \\
\hline \multicolumn{2}{|c|}{$\begin{array}{l}\text { Accumulated to This Day } \\
\text { Management Expenses }\end{array}$} & $278,855.08$ & $1,257.02$ & $116,784.72$ & $1,272.86$ & $141,489.37$ & $1,528.70$ & $122,720.38$ & $1,433.04$ \\
\hline \multicolumn{2}{|l|}{ Total Expenses } & $333,740.71$ & $1,504.43$ & $142,315.48$ & $1,551.12$ & $162,618.60$ & $1,756.98$ & $142,917.58$ & $1,668.89$ \\
\hline
\end{tabular}

Different investment costs have been calculated according to irrigation systems in studies conducted. In a study conducted by Gültaş and Erdem (2007), they calculated their investment costs as $\$ 30,848.22$ for drip irrigation method and \$26,293.98 for micro sprinkler irrigation method. While converting these values into dollars, the dollar exchange rate of $2007(1.308 \mathrm{TL} / \$)$ is utilized. Therefore, they stated that micro sprinkler irrigation system would be preferable if water source is sufficient. In a study conducted by Prevatt et al. (1992), they determined the operating costs of the drip irrigation system as \$ 144.94 and the investment costs as \$338.77. Lamm et al. (2002) in the maize production of furrow irrigation method underwater drop and moving sprinkler irrigation system land width, land shape, system costs and the lifetime of the comparison are compared. They stated that moving sprinkler irrigation systems would be more advantageous in enterprises with a minimum width of 65 ha. Dumler et al. (2007) in a study they conducted determined that the investment cost of the drip irrigation systems was $\$ 443.90$ and the investment cost of circular moving irrigation systems is \$292.14. In 2001, Armstrong et al. (2001) calculated the investment costs of irrigation systems within the framework of intelligent irrigation methods. Accordingly, it has been determined that the investment costs of circular moving irrigation systems are 2.500-3.500 $\$$ for 50 ha land and the investment costs of linear moving irrigation systems are higher. Sprinkler irrigation systems range from $\$ 1,750-2,500$ for 20 ha and drip irrigation systems for 10 ha of land vary between $\$ 5,000-12,000$. In Ernst (2017), in a study on irrigation systems, the cost of drip irrigation systems is determined as $\$ 638.90$ / ha. In addition, the management costs of drip irrigation systems is $\$ 305.73$. In 1983, Sourell and Schoen (1983) compared surface, drip and sprinkler irrigation systems. As a result of comparison, they determined that, in terms of investment and energy costs, drip irrigation systems are more economical than other systems. In a study by Harris et al. (2017), calculated the investment costs of different irrigation systems. Accordingly, the investment costs of circular moving irrigation systems are $\$ 338.00$ / ha and the investment cost of underground drip irrigation systems is $\$ 1,200$ / ha. In another study, the investment cost of circular moving irrigation system for 160 is calculated and the investment cost per decade was determined as \$ 1,212.99. Moll (1996) study in Australia in 1996 and Giddings and Deegenaars (1999) study in Australia in 1999 are similar. Both studies are carried out in vineyard areas and 
different irrigation systems are compared. Moll aims to reveal the economic system between these five systems by comparing the furrow, pan, micro sprinkler, sprinkler, and drip irrigation systems. According to the study, pan and drip irrigation system is found to be more profitable than the other systems in terms of the net present value in the five systems. In the study conducted by Giddings and Deegenaars, different irrigation systems are compared, and it is determined that drip irrigation system is more economical than other systems. And it is determined that the investment is taken back nearly 4 times. In another study conducted in Sri Lanka, in banana gardens surface irrigation and drip irrigation system were compared in terms of cost by using 10 years data. The cost of the drip irrigation system is calculated over a 10 ha area and the initial investment cost of the drip irrigation system is $43 \%$ higher than the surface irrigation. Although the investment cost is high in the drip irrigation system, the benefit expense ratio, internal rate of return, yield and net income are higher than surface irrigation (Thadchayini and Thiruchelvam 2005).

While calculating the accumulated management costs in sprinkler and drip irrigation systems, the total of $15-$ year operating expenses in sprinkler and drip irrigation systems has been reduced to today and the sum of 30-year operating expenses in circular and linear moving irrigation systems has been reduced to this day (Ağızan, 2018). The accumulated management costs per enterprise have been calculated as $\$ 278,855.08$ in the sprinkler system, $\$ 116,784.72$ in the drip irrigation system, $\$ 141,489.37$ in the circular moving irrigation system and $\$ 122,720.38$ in the linear moving irrigation system. The total cost per enterprise is $\$ 333,740.71$ in the sprinkler irrigation system, $\$ 142,315.48$ in the drip irrigation system, $\$ 162,618.60$ in the circular moving irrigation system and $\$ 142,917.58$ in the linear moving irrigation system. The lowest cost management in accumulated management cost to this day is the sprinkler irrigation system $(\$ 1,257.02)$, and the highest the circular moving irrigation system $(\$ 1,528.70)$. However, since the utilization life of sprinkler irrigation systems is 15 years, sprinkler irrigation systems should be renewed every 15 years. This will increase investment costs in sprinkler irrigation systems. Circular and linear moving irrigation systems are renewed every 30 years. So, moving systems are more advantageous than sprinkler and drip irrigation systems. It has been found that for the accumulated management cost to this day linear mobile irrigation system $(\$ 1,433.04)$ is lower than other systems at the operating cost per decare (Table 2). In a study by Morris (1999), the methods of sprinkler and drip irrigation were investigated and stated that drip irrigation systems should be used in terms of total costs and operating costs.

In Table 3, according to the irrigation systems, average cultivation areas, average productivity and average product prices obtained by the producer are multiplied and the gross value of the investment for products are calculated. And by adding these, the gross production values of the investment areas are calculated. In the examined enterprises, it is determined that the area is irrigated with sprinkler irrigation system at 19,300 dec, a total of 4,635,888.07 $\$ \mathrm{GPV}$ is obtained from this area and it is a total variable cost of $28,180.66 \$$. Drip irrigation system is used in 3,670 decare. The total GVP obtained with the drip irrigation system is $\$ 1,011,867.28$ and the total variable cost per enterprise is $\$ 11,395.36$. Circular moving irrigation system is established on 833 area and total production value is $320.539 .07 \$$. Total variable cost per enterprise is $14,590.92 \$$. Linear moving irrigation system is used in 942 area. Total GVP 352,858.39 \$ obtained through linear moving irrigation system and total cost per enterprise is $\$ 12,224.58$. According to these results, it is necessary to use linear moving irrigation systems in terms of both GVP and gross profit. As a matter of fact, this situation is expressed in the studies (Tuzcu 2010).

Table 3 shows the reduced GVP, reduced expense and reduced benefit by taking the reduced coefficients into account according to the interest rates for irrigation systems. For these values, 15 years in sprinkler and drip irrigation systems and 30 years in circular and linear moving irrigation systems are calculated. Although the minimum and maximum interest rate of each system is changing, the calculation of the discount coefficients is made according to the interest rates. In the reduced GVP calculation, for the system with the discount coefficient of the interest rate calculated and a reduced GVP is obtained by multiplying the total GVP per decare. In the reduced expense calculation, the total investment cost per decares is taken into consideration for the first year; in the second year and in the following years, the total management cost is calculated per decare. Reduced cost of the system obtained by multiplying the investment and management costs per decare as systems with discounting coefficients for applied interest rate. Annual net profit is obtained by subtracting total enterprise and investment costs per decare from total GPV per decare. Reduced benefit obtained by multiplying the net profit for years with discounting coefficients for applied interest rate. 
JOTAF/ Journal of Tekirdag Agricultural Faculty, 2021, 18(2)

Table 3. Investment Areas, GVP And Variable Costs by Products According to Irrigation Systems

\begin{tabular}{|c|c|c|c|c|c|c|c|c|c|}
\hline & \multirow{2}{*}{ Products } & \multirow{2}{*}{$\begin{array}{c}\text { Cultivation } \\
\text { Area } \\
\text { da }\end{array}$} & \multirow{2}{*}{$\begin{array}{l}\text { Productivity } \\
\qquad \mathrm{Kg} / \mathrm{da}\end{array}$} & \multirow{2}{*}{$\begin{array}{l}\text { Price } \\
\text { \$/kg }\end{array}$} & \multicolumn{3}{|c|}{ GVP (\$) } & \multicolumn{2}{|c|}{ Variable Cost (\$) } \\
\hline & & & & & Total & $\begin{array}{c}\text { Per } \\
\text { Enterprise }\end{array}$ & $\begin{array}{c}\text { Per } \\
\text { Decares }\end{array}$ & $\begin{array}{c}\text { Per } \\
\text { Enterprise }\end{array}$ & $\begin{array}{c}\text { Per } \\
\text { Decares }\end{array}$ \\
\hline \multirow{9}{*}{ 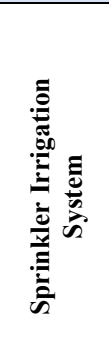 } & Wheat & $5,365.00$ & 542.36 & 0.22 & $650,867.68$ & $7,481.24$ & 121.32 & $4,508.31$ & 73.11 \\
\hline & Barley & $3,569.00$ & 503.69 & 0.19 & $340,611.08$ & $3,915.07$ & 95.44 & $2,772.05$ & 67.57 \\
\hline & Sugar beet & $4,030.00$ & $7,956.36$ & 0.06 & $1,771,965.12$ & $20,367.42$ & 439.69 & $10,848.18$ & 234.19 \\
\hline & Grain Maize & $1,995.00$ & $1,389.63$ & 0.19 & $539,871.26$ & $6,205.42$ & 270.61 & $3,387.15$ & 147.71 \\
\hline & Silage Maize & $1,073.00$ & $7,105.36$ & 0.04 & $321,012.68$ & $3,689.80$ & 299.17 & $1,749.00$ & 141.81 \\
\hline & Sunflower & $1,156.00$ & 345.69 & 0.45 & $178,776.31$ & $2,054.90$ & 154.65 & $1,320.38$ & 99.37 \\
\hline & Clover & $1,263.00$ & $1,425.36$ & 0.13 & $241,609.77$ & $2,777.12$ & 191.30 & $2,208.16$ & 152.11 \\
\hline & Vetch & 489.00 & 990.00 & 0.16 & $76,438.42$ & 878.60 & 156.32 & 556.21 & 98.96 \\
\hline & Carrot & 360.00 & $7,546.28$ & 0.19 & $514,735.73$ & $5,916.50$ & $1,429.82$ & 831.23 & 200.88 \\
\hline \multirow{10}{*}{ 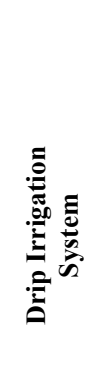 } & Total & $19,300.00$ & & & 4,635,888.07 & $53,286.07$ & 240.20 & $28,180.66$ & 127.03 \\
\hline & Wheat & $1,049.00$ & 589.23 & 0.22 & $138,259.72$ & $3,456.49$ & 131.80 & $1,737.61$ & 66.26 \\
\hline & Barley & 485.00 & 545.36 & 0.19 & $50,115.71$ & $1,252.89$ & 103.33 & 733.08 & 60.46 \\
\hline & Sugar beet & 828.00 & $8,256.36$ & 0.06 & $377,793.65$ & $9,444.84$ & 456.27 & $4,694.64$ & 226.79 \\
\hline & Grain Maize & 499.00 & $1,497.26$ & 0.19 & $145,494.27$ & $3,637.36$ & 291.57 & $1,721.11$ & 137.97 \\
\hline & Silage Maize & 297.00 & $7,625.47$ & 0.04 & $95,358.51$ & $2,383.96$ & 321.07 & 975.82 & 131.42 \\
\hline & Sunflower & 192.00 & 387.61 & 0.45 & $33,293.66$ & 832.34 & 173.41 & 437.38 & 91.12 \\
\hline & Clover & 118.00 & $1,675.38$ & 0.13 & $26,532.73$ & 663.32 & 224.85 & 420.49 & 142.54 \\
\hline & Vetch & 122.00 & $1,152.36$ & 0.16 & $22,198.09$ & 554.95 & 181.95 & 285.22 & 93.52 \\
\hline & Carrot & 80.00 & $8,102.77$ & 0.19 & $122,820.93$ & $3,070.52$ & $1,535.26$ & 389.99 & 194.99 \\
\hline \multirow{5}{*}{ 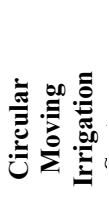 } & Total & $3,670.00$ & & & $1,011,867.28$ & $25,296.68$ & 275.71 & $11,395.36$ & 124.20 \\
\hline & Sugar beet & 386.00 & $8,423.30$ & 0.06 & $179,682.29$ & $19,964.70$ & 465.50 & $8,663.98$ & 202.01 \\
\hline & Grain Maize & 332.00 & $1,590.23$ & 0.19 & $102,812.56$ & $11,423.62$ & 309.68 & $4,445.48$ & 120.51 \\
\hline & Silage Maize & 115.00 & $7,856.96$ & 0.04 & $38,044.23$ & $4,227.14$ & 330.82 & $1,481.46$ & 115.94 \\
\hline & Total & 833.00 & & & $\mathbf{3 2 0 , 5 3 9 . 0 7}$ & $35,615.45$ & 384.80 & $14,590.92$ & 157.64 \\
\hline \multirow{4}{*}{ 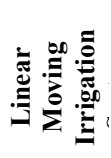 } & Sugar beet & 276.00 & $8,652.49$ & 0.06 & $131,973.24$ & $11,997.57$ & 478.16 & $5,054.44$ & 201.44 \\
\hline & Grain Maize & 499.00 & $1,687.53$ & 0.19 & $163,983.51$ & $14,907.59$ & 328.62 & $5,416.31$ & 119.40 \\
\hline & Silage Maize & 167.00 & $8,092.30$ & 0.04 & $56,901.65$ & $5,172.88$ & 340.73 & $1,753.84$ & 115.52 \\
\hline & Total & 942.00 & & & $352,858.39$ & $32,078.04$ & 374.58 & $12,224.58$ & 142.75 \\
\hline
\end{tabular}

Table 4 shows the results of investment analysis according to irrigation systems in examined enterprises. The cost-benefit ratio, NPV and IRR is found for each irrigation system. In the analysis, the lowest interest rate of $16 \%$ is used. Ziraat Bank's interest rates for non-subsidized agricultural loans are taken into consideration. The highest interest rates are those that make the benefits of the systems positive for the last time. That is to say, the maximum interest rates that make a positive increase are considered because the highest interest rate will be increased by one unit. In the calculation of the analysis, the cost of benefit ratio is calculated by dividing the present value of the net income of the investments by the sum of the present value of the investment expenses. In the calculation of NPL, the total of the present value of the investment expenses is subtracted from the sum of the present values of the net income of the investments. As a result of the analyzes, the benefit expense ratio is bigger than 1 and the IRR is lower than the low interest rate $(16 \%)$ means that the project is economic. In case the IRR is higher than the capital cost $(16 \%)$, the enterprises are not affected by inflation, they met the capital costs and made a profit.

If the cost-benefit ratio is greater than 1 , it means that the income of the project is greater than the investment. In the 4 irrigation systems included in the study, the benefit ratio was found to be greater than 1 . In Other words, provided more than 1 \$ benefit for each $\$ 1$ investment. In sprinkler irrigation system, provided $1.02 \$$ benefit for each $1 \$$ investment. In drip irrigation system provided $1.13 \$$ benefit, in circular moving irrigation system 1.54 $\$$ benefit, and in linear moving irrigation system provided 1.57 benefit. According to Balaban (1986), if the costbenefit ratio is greater than 1, it means that the project is economic. As a matter of fact, other studies (Talmaç 2006, Atabey and Erdem 2016) prove this situation. 


\begin{tabular}{ccccccc}
\hline \multirow{2}{*}{ Irrigation Systems } & \multicolumn{3}{c}{ Lowest Interest Rate } & \multicolumn{3}{c}{ Highest Interest Rate } \\
& $\begin{array}{c}\text { Reduced } \\
\text { Net İncome }\end{array}$ & $\begin{array}{c}\text { Reduced } \\
\text { Expense }\end{array}$ & $\begin{array}{c}\text { Reduced } \\
\text { Benefit }\end{array}$ & $\begin{array}{c}\text { Reduced } \\
\text { Net İncome }\end{array}$ & $\begin{array}{c}\text { Reduced } \\
\text { Expense }\end{array}$ & $\begin{array}{c}\text { Reduced } \\
\text { Benefit }\end{array}$ \\
\hline $\begin{array}{c}\text { Sprinkler } \\
\text { Drip }\end{array}$ & $1,338.88$ & $1,312.98$ & 25.90 & $1,171.19$ & $1,179.52$ & -8.33 \\
Circular Moving & $1,536.83$ & $1,357.26$ & 179.56 & 929.88 & 931.13 & -1.25 \\
Linear Moving & $2,376.99$ & $1,543.99$ & 833.00 & 506.32 & 508.54 & -2.22 \\
\hline
\end{tabular}

$\mathrm{NPV}$ is found $25.90 \$$ in sprinkler irrigation system,179.56 $\$$ in drip irrigation system, $833.00 \$$ in circular moving irrigation system and $844.66 \$$ in linear moving irrigation system. The lowest interest rate in the internal rate of return is $16 \%$ for all systems. In the sprinkler irrigation system, the highest interest rate is $19 \%$ and IRR $20.42 \%$ is calculated. The highest interest rate in the drip irrigation system is $29 \%$ and the IRR is $29.09 \%$. The highest interest rate in circular and linear moving irrigation systems determined as $76 \%$. IRR calculated. $\% 76.16$ in circular moving irrigation system, and \%76.41 in linear moving irrigation system if IRR is greater than \%16 it means that project is economic. It is determined that the IRR of 4 irrigation system is higher than capital cost (Table 5).

Table 5. Investment Analysis Results for Irrigation Systems in the Enterprises Examined

\begin{tabular}{|c|c|c|c|c|c|c|c|c|c|}
\hline \multirow[t]{2}{*}{ Method } & \multirow[t]{2}{*}{ Component } & \multicolumn{2}{|c|}{$\begin{array}{c}\text { Sprinkler } \\
\text { Irrigation Systems }\end{array}$} & \multicolumn{2}{|c|}{ Drip İrrigation Systems } & \multicolumn{2}{|c|}{$\begin{array}{l}\text { Circular Moving } \\
\text { İrrigation Systems }\end{array}$} & \multicolumn{2}{|c|}{$\begin{array}{c}\text { Linear Moving } \\
\text { İrrigation Systems }\end{array}$} \\
\hline & & Values & Result & Values & Result & Values & Result & Values & Result \\
\hline Benefit Cost & $\mathrm{F}$ & $1,338.88$ & \multirow{2}{*}{1.02} & $1,536.83$ & \multirow{2}{*}{1.13} & $2,376.99$ & \multirow{2}{*}{1.54} & $2,313.88$ & \multirow{2}{*}{1.57} \\
\hline Ratio & M & $1,312.98$ & & $1,357.26$ & & $1,543.99$ & & $1,469.22$ & \\
\hline Net Present & $\mathrm{F}$ & $1,338.88$ & \multirow{2}{*}{25.90} & $1,536.83$ & \multirow{2}{*}{179.56} & $2,376.99$ & 02300 & $2,313.88$ & \multirow{2}{*}{844.66} \\
\hline Value & M & $1,312.98$ & & $1,357.26$ & & $1,543.99$ & 833.00 & $1,469.22$ & \\
\hline \multirow{4}{*}{$\begin{array}{l}\text { Internal } \\
\text { Rate of } \\
\text { Return }\end{array}$} & $\mathrm{R}_{1}$ & $16 \%$ & \multirow{4}{*}{$20.42 \%$} & $16 \%$ & \multirow{4}{*}{$29.09 \%$} & $16 \%$ & & $16 \%$ & \multirow{4}{*}{$76.41 \%$} \\
\hline & $\mathrm{R}_{2}$ & $19 \%$ & & $29 \%$ & & $76 \%$ & $7616 \%$ & $76 \%$ & \\
\hline & $\mathrm{ND}_{1}$ & 25.90 & & 179.56 & & 833.00 & & 844.66 & \\
\hline & $\mathrm{ND}_{2}$ & -8.33 & & -1.25 & & -2.22 & & -5.69 & \\
\hline
\end{tabular}

F: The present value of net revenues of investments in the comparison period

M: The present value of investment expenses in the comparison period

$\mathrm{R}_{1}$ : Selected Low Interest Rate

$\mathrm{R}_{2}$ : Selected High Interest Rate

$\mathrm{ND}_{1}$ : The present value of the net income of the investment at low interest rate in the comparison period

$\mathrm{ND}_{2}$ : The present value of the expenses of the investment at the high interest rate in the comparison period

Profitability ratio is found by subtracting the capital cost from IRR. According to Table 5, profitability ratio in sprinkler irrigation system is determined $\% 4.42$, in drip irrigation system $\% 13.09$, in circular moving irrigation system $\% 60.16$ and in linear moving irrigation system $\% 60.41$.

According to the results of investment analysis, it is determined that the most advantageous system is linear moving irrigation system. Linear moving irrigation system provides more benefit to enterprises in terms of benefit / cost ratio, NPV, IRR and rate of profit compared to other systems.

Turkey is determined to studies conducted so far generally drip and sprinkler irrigation systems is the investment analysis made of the drip irrigation system in these studies benefit expense ratio and net present values were higher than other irrigation systems (Soydam and Cakmak, 2006; Atabey and Erdem, 2016). In addition, Çetin et al. (2004) calculated the costs of irrigation systems and calculated the investment costs of drip irrigation systems at $\$ 2.244$ / ha and net benefit at \$ 3.464 / ha.

\section{Conclusions}

Along with the different crops being grown in agricultural enterprises, the costs of each product are different, and the investment costs also differ between the crops. In this regard, the production patterns in the agricultural 
establishments examined were determined which irrigation systems were used in which products, and investment analyzes were carried out over decares of the products according to the irrigation systems.

Products in the study conducted the most preferred irrigation system in terms of products is sprinkler irrigation system. The most irrigated products by sprinkler and drip irrigation systems are wheat and barley. While the most irrigated products in the circular irrigation system are sugar beet and grain, the grain maize is the first in the linear moving irrigation system with $52.97 \%$.

Total expenses of irrigation systems obtained by adding the investment expenses to the accumulated enterprise expenses. While calculating the accumulated enterprise expenses, in drip irrigation system the 15 years expenses are reduced today and in circular and linear moving irrigation system the 30 years expenses reduced today. The linear cost-effective irrigation system $(\$ 1,668.89)$ is the most advantageous system because of the economic life of the systems, although the lowest cost to the decare at the total costs is the lowest cost of sprinkler irrigation system $(\$ 1,504.43)$ and the highest cost circular moving irrigation system $(\$ 1,756.98)$.

Due to its economic life, sprinkler irrigation systems need to be renewed every 15 years and this increases the investment costs of the system. For this reason, the most cost-effective system in total costs per decare is not a sprinkler irrigation system but a linear moving irrigation system. The cost-benefit ratio, NPV and IRR is found for each irrigation system. According to the results of investment analysis, the most advantageous system among the systems is linear moving irrigation system. With this system it is determined that provided $157 \$$ benefit for each $1 \$$ investment according to the benefit-cost ratio. NPV is calculated as 844.66 . It is considered that the lowest interest rate for the linear moving irrigation system is $16 \%$ and the highest interest rate is $76 \%$. According to selected interest rates, IRR calculated as $\% 76.41$ and as a result it is determined that system is economic. Profit ratio is determined as $\% 60.41$.

As a result, irrigation systems that save water in agricultural irrigation, increase the productivity and quality achieved in the unit area and reduce the labor need should be preferred. In addition, the irrigation system is preferred in terms of product variety and land width is considered, but the investment cost of the irrigation system and economic life also affects the preference. Preferred irrigation systems should be technically and economically consistent with the enterprise. Manufacturers should consider economic consistency as well as technical consistency when deciding between systems. In fact, it is very important in terms of profitability of the enterprise to determine which of the irrigation systems are more economical.

While fragmented and dispersed lands make the use of mobile irrigation systems difficult to use, it is necessary to use and disseminate especially linear moving irrigation systems to protect the water resources, increase the quantity and quality of the product obtained in the unit area and reduce the labor force required for irrigation. Therefore, agricultural land consolidation efforts should be increased, linear mobile irrigation systems should be supported, and producers should be informed about irrigation. In addition, the supply of water resources should be increased, producers should be encouraged to use water saving, and water losses should be minimized until the water is taken from the source to the plant root zone.

\section{Acknowledgment}

This work supported by the Selcuk University Research Project (Project No: 17201054) Turkey. 


\section{References}

Ağızan, S. (2018). Sulama Sistemlerin Karşılaştırmalı Yatırım Analizi; Konya İli Çumra İlçesi Örneği. (Yüksek Lisans Tezi), Selçuk Üniversitesi Fen Bilimleri Enstitüsü. 286.

Akgüç, Ö. (1994). Finansal Yönetim. Avcıol Basım Yayınpp.

Albayrak, B. (2009). Proje yönetimi ve analizi: Nobel Yayın Dağıtım, 582 pp.

Anonim. (2017). Geçmiş Tarihli Amerikan Doları. (Web page: http://paracevirici.com/doviz-arsiv/merkez-bankasi/gecmistarihli-doviz/2017/amerikan-dolari) (Date accessed: 18.03.2019).

Armstrong, D., O'Donnell, D., Thompson, C. (2001). Sulama Ekipmanları ve Teknikleri. Department of Primary Industries Water and Enviroment, Tasmania.

Atabey, B., Erdem, T.(2016). Trakya Bölgesi Koşullarında Damla Sulama Uygulamalarının Ekonomik Açıdan Değerlendirilmesi. Journal of Adnan Menderes University, Agricultural Faculty, 13(1): 53-61.

Balaban, A. (1986). Su Kaynaklarının Planlanması. Ankara Üniv. Zir. Fak. Yayınları, 972.

Çakmak, B., Gökalp, Z., Demir, N. (2014). Sınıraşan nehir havzalarda tarımda su kullanımının değerlendirilmesi. Tekirdağ Ziraat Fakültesi Dergisi, 11(2): 119-129.

Çetin, B., Yazgan, S., Tipi, T. (2004). Economics of drip irrigation of olives in Turkey. Agricultural Water Management, 66(2): 145-151.

Demir, A.O., Korukçu, A., Yazgan, S. (1995). Bursa Koşullarında Karık ve Damla Sulama Yöntemleri ile Sulanan Çileğin Verim ve Sulama Suyu Gereksinimi 5. Ulusal Kültürteknik Kongresi Bildirileri, Kültürteknik Derneği 30 Mart - 2 Nisan 1995: 423-436.

Dumler, T.J., Rogers, D.H., O'Brien, D.M. (2007). Irrigation capital requirements and energy costs: Agricultural Experiment Station and Cooperative Extension Service, Kansas State Universitypp.

Erdem, T. (2018). Farklı Sulama Suyu Uygulamalarının Badem Ağaçlarının Su Kullanımı ve Vegetatif Gelişme Parametrelerine Etkileri. Tekirdağ Ziraat Fakültesi Dergisi, 15(1): 86-94.

Ernst, M. (2017). Irrigation Systems. CCD-FS-1. Lexington, KY: Center for Crop Diversification, University of Kentucky College of Agriculture, Food and Environment.

Giddings, J., Deegenaars, A. (1999). Managing the conversion to drip irrigation in vineyards. Australian Government. Grape and wine research and development corperation.

Gültaş, H.T., Erdem, Y. (2007). Bodur Kiraz Bahçelerinde Damla ve Mikro Yağmurlama Sulama Yöntemlerinin Yatırım ve İşletme Masraflan Yonunden Karşılaştııılması. Tarım bilimleri dergisi, 13(1): 38-46.

Harris, M.O., Anderson, K., El-Bouhssini, M. (2017). Wheat pests: insects, mites, and prospects for the future University, USA; Gary Hein, University of Nebraska, USA; and Steven Xu, USDA-ARS Northern Crops Institute, USA, 523-600 Achieving sustainable cultivation of wheat Volume 1, Burleigh Dodds Science Publishing, 523-600 pp.

Kavak, K. (2012). Proje Analizinde Kullanılan Teknikler. (Web page: http://www.dektmk.org.tr/upresimler/KKAVAK-1.pdf) (Date accessed: 14.09.2017).

Lamm, F., O’Brien, D., Rogers, D., Dumler, T.(2002). Sensitivity of center pivot sprinkler and SDI economic comparisons. Paper presented at the ASAE Meeting Paper No. MC02-201. St. Joseph, MI.

Moll, J. (1996). Financial Analysis of New Vineyard Developments inThe MIA (pp. 32).

Morris, J. (1999). Evaluating Drip Irrigation in Eastern Vineyards. WE, 24(4): 16-21.

Prevatt, J., Clark, G., Stanley, C. (1992). A comparative cost analysis of vegetable irrigation systems. HortTechnology, 2(1): 91-94.

Senkondo, E., Msangi, A., Xavery, P., Lazaro, E., Hatibu, N. (2004). Profitability of rainwater harvesting for agricultural production in selected semi-arid areas of Tanzania. Journal of Applied Irrigation Science, 39(1): 65-81.

Sourell, H., Schoen, H. (1983). Water and energy saving irrigation methods. Landtechnik (Germany, FR), 38(9): 356-361.

Soydam, A., Cakmak, B. (2006). Toplu Basıçılı Sulama Sistemlerinin Ekonomik Yönden Karşılaştırılması; Yaylak Projesi 1400 Nolu Yedeği Örneği. Tarım bilimleri dergisi, 12(1): 74-78.

Sutema. (2017). Suyun Sektörlere Göre Kullanım Oranları. (Web page: http://sutema.org/kirilgan-dongu/suyun-sektorleregore-kullanim-oranlari.9.aspx) (Date accessed: 14.09.2017)

Talmaç, B. (2006). Harran Ovasında Farklı Sulama Yöntemlerinin Ekonomik Analizi. Harran Üniversitesi Fen Bilimleri Enstitüsü Yüksek Lisans Tezi. 60s. Adana. 
Thadchayini, T., Thiruchelvam, S. (2005). An economic evaluation of drip irrigation project for banana cultivation in Jaffna district, 111-126. Paper presented at the Water resources researches in Sri Lanka. Ed. LG Galagedara.. Symposium proceedings of the Water Professional's Day.

Tuzcu, T. (2010). Adana İli Tarım İşletmelerinde Basınçlı Sulama Sistemlerinin Kullanımı ve Ekonomik Yönden Karşılaştırılması. Kahramanmaraş Sütçü İmam Üniversitesi Fen Bilimleri Enstitüsü, Tarım Ekonomisi Anabilim Dalı Yüksek Lisans Tezi, Kahramanmaraş. 